\title{
GLORIA DEI AS A KEY TO UNDERSTAND CALVIN'S DOCTRINE OF PREDESTINATION ${ }^{1}$
}

\author{
Billy Kristanto \\ International Reformed Evangelical Seminary, Jakarta
}

\begin{abstract}
ABSTRAK: Artikel ini menganalisa doktrin predestinasi dalam pemikiran Calvin dan menawarkan sebuah alternatif untuk mengerti doktrin ini ditinjau dari perspektif kemuliaan Allah. Melalui argumentasi-argumentasi historis dan sistematis, penulis menawarkan sebuah pemikiran kunci untuk mengerti kompleksitas dari doktrin predestinasi Calvin. Ide kemuliaan Allah dapat menjadi sebuah kunci untuk mengerti doktrin ini.
\end{abstract}

KATA KUNCI: pilihan, reprobasi, predestinasi ganda, Karl Barth, potential absoluta dei, Katekismus Besar Westminster.

ABSTRACT: This article analyses the doctrine of predestination in Calvin's thought and offers an alternative to understand it from the perspective of the glory of God. With historical and systematic theological argumentations, the writer offers a key thought for understanding the complexity of Calvin's doctrine of predestination. The idea of the glory of God can serve as a key to understand the doctrine.

1 Part of this article is taken from the author's dissertation Sola Dei Gloria: The Glory of God in the Thought of John Calvin (Frankfurt am Main, et al.: Peter Lang, 2011), 128-135. 
KEYWORDS: election, reprobation, double predestination, Karl Barth, potentia absoluta dei, Westminster Larger Catechism.

\section{The Placement of Predestination in Calvin's Institutes}

The well-known doctrine of predestination, sometimes incorrectly said as the center of Calvin's theology, ${ }^{2}$ is placed in the Institutes interestingly almost at the end of the third book, before the last chapter on the final resurrection. One would rather expect the placement of this doctrine at the beginning of soteriology. In fact, already in the Institutes III, 11 an earlier 'confusion' occurred when Calvin treated justification by faith after the Christian life (Ch. 6-10). Certainly, the Christian life is not understood as an experience of theologiacrucis in the context of Luther's theological/spiritual use of the law which leads to the Gospel. It belongs rather to the benefits that come to us and the effects which follow from the grace of Christ, as the title of the third book suggests. Faith and regeneration were treated before the Christian life in ICR III, 2-3, so that the treatment from faith to faith serves as a frame in Ch. 2-11 with the Christian life as its center. Despite the high standard of Christian life, Calvin clearly holds a forensic doctrine of justification by faith alone. The framing structure from faith to faith might function as a safeguard from false interpretation concerning the Christian life. On the other side, it cannot be denied that justification follows Christian life. If Luther had stood the via triplex of medieval mysticism - the purging

2 Comp. Alexander Schweizer, Die Protestantischen Centraldogmen in ihrerEntwicklung innerhalb der reformierten Kirche, 2 vols. (Zürich, 1854-56), 1:5, 10-14; 367-72, 503-5, 2: 44; see also Richard A. Muller, "The Placement of Predestination in Reformed Theology," Calvin Theological Journal 40 (2005): 185-6. 
of $\sin$, the illumination of the Holy Spirit, union with God - on its head, ${ }^{3}$ it seems that Calvin maintains to a certain extent the older structure which has the mystic union with God (Christ) as its end. However, Calvin did modify the order he borrowed from the medieval spirituality: if the via triplex had begun with the purgation of sins followed by the illumination of the Holy Spirit and completed with mystic union with God, Calvin - in the language of the via triplex - started with the illumination of the Holy Spirit, i.e. true faith arising as the work of the Holy Spirit. 4 The chapter of repentance then together with the chapters of Christian life (Ch. 6-10) - is parallel to the purging of sin. Finally the chapter of justification by faith (Ch. 11) onwards until the last chapter of the final resurrection (Ch. 25) can be compared with the mystic union with God. In this structure, the chapters of Christian life may be seen as a detail elaboration of what true repentance means.

\section{Predestination in Calvin's Response to Cardinal Sadolet}

Parallel to the framing structure of faith (III,2-11), the placement of the doctrine of election could be seen as another effort to safeguard what comes between justification (by faith alone) and eternal election. In the middle of this second framing stands the danger of boasting about the merits of works to the false relation between works-righteousness and salvation (Ch. 16-18).

3 Richard F. Lovelace, "Evangelical Spirituality," in Exploring Christian Spirituality: An Ecumenical Reader, ed.Kenneth Collins (Grand Rapids: Baker Books, 2000), 216.

4 “Verum (quae mentis nostrae ad vanitatem est propensio) Dei veritati nunquam adhaerere potest: quae hebetudo est, ad eius lucem semper caecutit. Proinde, sine Spiritus sancti illuminatione, verbo nihil agitur.Unde etiam liquet fidem humana intelligentia multo superiorem esse." Calvin, Institutio Christianae Religionis [=ICR] III, 2, 33, in Joannis Calvini Opera Selecta[=OS] 4, ed. P. Barth/W. Niesel/D. Scheuner, 5 vols., 1926-1936, vol. 3, München: Kaiser, 1928, 44, 6-11. 
This is hardly a new structure, since it was already used by Calvin in his earlier writing of 1539: the Response to Cardinal Sadolet. In stating sermon (concio) and doctrine (doctrina) as one of the triple foundation of the church, Calvin subdivides his explanation into three subjects of justification by faith, works, and election by grace. It is explained that (good) works are flowing from both justification by faith and election of grace. Both justification and election have the same goal, namely a pure and unpolluted life before God: Quin potius, ut gratuita electio [399] finem hunc habet, ut vitam coram Deo traducamus puram et impollutam, sic et gratuita iustificatio. ${ }^{5}$

The election has its foundation in God's love, so that the glory of the expiation sacrifice in the blood of Christ cannot be transferred to our works, even to the church. ${ }^{6}$ In this earlier writing, with its relation with God's love, election is more understood as God's gracious act rather than as God's decree.

Similar to his response to Cardinal Sadolet, in his Institutes Calvin also uses the doctrine of election not in a chronological order in the ordosalutis but - together with the doctrine of justification - as a confirmation on the absurdity of boasting about the merits of works in the context of salvation. The doctrine of election is here used again to secure the right interpretation on the place of works and Christian life. However, in this last edition of the Institutes, eternal election is understood as predestination, i.e. in the strong

5 Calvin, "Iacobi Sadoleti Romani Cardinalis Epistola ad Senatum populumque Geneuensem, qua in obedientiam Romani Pontificis eos reducere conatur. Ioannis Caluini Responsio. Argorati per Vuendelinum Rihelium. Mense Septembri. Anno M.D.XXXIX", in: Calvin-Studienausgabe, Bd. 1, Teilband 1/2, ed. Eberhard Busch, etc. (Neukirchen-Vluyn: Neukirchener, 1994), 380, 21-23.

6 Ibid., 382, 12-15. 
relation with God's decree.

The understanding of the doctrine of election as God's decree can be explained from the perspective of gloria Dei. Not knowing the doctrine of predestination impairs God's glory and our humility. ${ }^{7}$ The true glory, i.e. not seeking one's own glory, should restrain us from searching after foolish knowledge beyond the limit of what the Word of God reveals. ${ }^{8}$ That predestination cannot be understood and explained exhaustively without any mystery should not astonish us since with Solomon we can say, "It is the glory of God to conceal the word [Prov. 25:2, Vg.]." ${ }^{\prime 9}$ On the other hand, what God reveals in his Scripture should encourage us to study the doctrine of election. The reason of this doctrine is not to be found in anything external to God, but in God's good pleasure. Subjoined with God's good pleasure is "the whole intent of our election", namely that "we should be to the praise of divine grace [cf. Eph. 1:6]". ${ }^{10}$ Thus the gloria Dei provides the repudiation on human merits in the consideration of election.

\section{Calvin and the Medieval Theology}

Against Thomas who advocates the thought of predestination to grace to merit glory, ${ }^{11}$ Calvin insists on the precedence of predestination to glory as the cause of predestination to grace. ${ }^{12}$ However, the distinction between

\footnotetext{
7 ICR III,21,1.

8 ICR III,21,2.

9 ICR III,21,3.

10 ICR III,22,3.

11 Cf. Summa TheologicaI,23,5.

12 ICR III,22,9.
} 
God's absolute and his ordained power traditionally used by earlier theologians such as Scotus and Ockham to safeguard the transcendent freedom of God and the radical contingency of creation is surprisingly criticized by Calvin. ${ }^{13}$ The legally trained Calvin cannot accept the notion of a lawless God; rather, God is a law to himself. In this context it is said that nothing greater than God's will, which is the supreme rule of righteousness, can be found. In the commentary on Gen. 25:29 God's will is said to be "the cause of causes". ${ }^{14}$ Here also the so-called absolute power of God is refuted by Calvin since it imputes rather tyranny to God than compassionate grace. Calvin's insistence on the supremacy of divine will should not be comprehended in the sense of an arbitrary divine sovereignty (therefore his rejection of God's absolute power), it is rather an emphasis on sola gratia Dei, which in turn should humble all flesh. ${ }^{15}$ In the commentary on Is. 23:9 Calvin calls the absolute power of God shocking blasphemy for it separates God's wisdom and justice from God's power thereby transforming God into a tyrant who determines to do everything in his pleasure through caprice. The acknowledgment of divine justice in God's works is the reason for ascribing glory to God alone. ${ }^{16}$ In the commentary on Gen. 18:13 the absolute

\footnotetext{
13 "We, however, give no countenance to the fiction of absolute power, which, as it is heathenish, so it ought justly to be held in detestation by us" ICR III,23,2; cf. David C. Steinmetz, Calvin in Context (New York: Oxford University Press, 1995), 40-41.

14 Calvin, Comm. Gen. 25:29.

15 "Et semper illud Pauli memoria tenendum est,neminem prae altero excellere sua industria aut virtute, sed sola Dei gratia. [...] Quare nihil aliud superest, nisi ut a facie Domini sileat omnis caro, ac totus mundus se obnoxium esse confitens eius iudicio humilietur potius quam superbe litiget" Calvin, Comm. Gen. 25:29, in Ioannis Calvini opera quae supersunt omnia (New York: Johnson, 1964), in Corpus Reformatorum [=CR] 51, 354.

16 Calvin, Comm. Is. 23:9.
} 
power of God is criticized because it separates God's power from his declared will, i.e. his Word. It is absurd to inquire what God can do apart from his Word. On the contrary, being persuaded to believe in God's power to fulfill his promise is an act of doxology. ${ }^{17}$ Thus for Calvin, not only does the notion of God's absolute power distract human beings from God's Word as his revealed will, it diminishes even the glory of God rather than advances it. Calvin is not interested in a theology that does not promote the faith of the believers. Lastly, in the commentary on Rom. 9:19 the so-called God's absolute justice is attacked by Calvin for in executing his will God cannot forget his own righteousness and thereby "throwing all things into confusion".$^{18}$ Though Calvin believes that the will of God is the highest rank, he earnestly rejects the idea of God's absolute power or absolute justice for its separation from other divine attributes. The most difficult issue that touches the understanding of divine will is perhaps that of reprobation.

\section{The Particular and Universal Aspect of Predestination: Predestination en Christo}

On one side, even not as obvious as Beza, ${ }^{19}$ Calvin understands that

\footnotetext{
17 "Videtur primo adspectu Paulus frigide laudare Abrahae fidem, quumdicit non considerasse corpus suum emortuum, sed dedisse gloriam Deo: quiapersuasusfuerit posse implere quod promiserat (Rom. 4, 19)" Calvin, Comm. Gen. 18:13, CR 51, 255.

18 Comm. Rom. 9:19.

19 In his dissertation, Rimbach has shown that one of the features of Beza's doctrine of predestination is his logical arrangement evident in the notion of election and reprobation as parallel ways in the execution of a single predestination. The center of the whole movement of thought is the gloria Dei: "Das Ziel der gesamten Bewegung ist erreicht, wenn Gottes Herrlichkeit in der Vollendung des Heils seiner Erwählten und in der ewigen Verdammung der Ungerechten aufstrahlt" Harald Rimbach, "Gnade und Erkenntnis," in Calvins Prädestinationslehre: Calvin im Vergleich mit Pighius, Beza und Melanchton (Frankfurt am Main, etc: Peter Lang, 1996), 29 [=Kontexte, Bd. 19]).
} 
the reason for reprobation is none others but God's sovereign will. In this respect, there is also a certain parallel between election (as predestination) and reprobation in Calvin's thought. He also notes that the Apostle Paul does not answer the question on divine justice concerning Esau's rejection and Jacob's acceptance with a defense that Esau had been recompensed according to his wickedness, but with the gloria Dei as its solution. ${ }^{20}$ The display of God's own glory is the sure reason that God's action is always just. There is an inseparable link between God's justice and gloria Dei. ${ }^{21}$ In this case, it cannot be said that Adam's fall was only permitted but not willed by God since for Calvin there is no permission that is not ordained by God. ${ }^{22}$ This is not to say that there is no distinction in God's working toward elect and the reprobate. In withdrawing the effectual agency of his Spirit in the manner of his call, God acts context-sensible. Also the withholding of his effective working is an expression of God's own glory. ${ }^{23}$ To encourage the obedient to a doxological life, the knowledge of predestination is therefore necessary. ${ }^{24}$ That is the very reason why the doctrine of predestination should be preached just as piety.

On the other side, this is not to say that there is no universalistic aspect in the preaching of predestination. Following Augustine, Calvin believes that since we do not know whom God has predestined to be saved

\footnotetext{
Such strict parallelization belongs arguably to the later development in Reformed theology.

20 ICR III,22,11.

21 “Ubi mentionem gloriae Dei audis, illic iustitiam cogita. Iustum enim esse oportet quod laudem meretur" ICR III, 23, 8, OS 4, 402, 36-38.

22 ICR III, 23,8 .

23 ICR III,24,2.

24 ICR III,23,13.
} 
and whom God has not, we ought to desire "that all men be saved". ${ }^{25}$ Calvin leaves thus no room for religious exclusivism that could arise from wrong application of the doctrine of predestination. It is not our part to judge human beings as condemned, rather "it belongs to God, however, to make that rebuke useful to those whom he . . has foreknown and predestined." 26 Moreover, the doctrine of election cannot be understood apart from Christ: "First, if we seek God's fatherly mercy and kindly heart, we should turn our eyes to Christ, on whom alone God's Spirit rests [cf. Matt. 3:17]." 27 Even the election en Christo is not originally Barth's idea, but is to be found in Calvin's Institutes: Accordingly, those whom God has adopted as his sons are said to have been chosen not in themselves but in his Christ [Eph. 1:4];28

In his commentary on Eph. 2:6, the rendering "in Christ" is to be

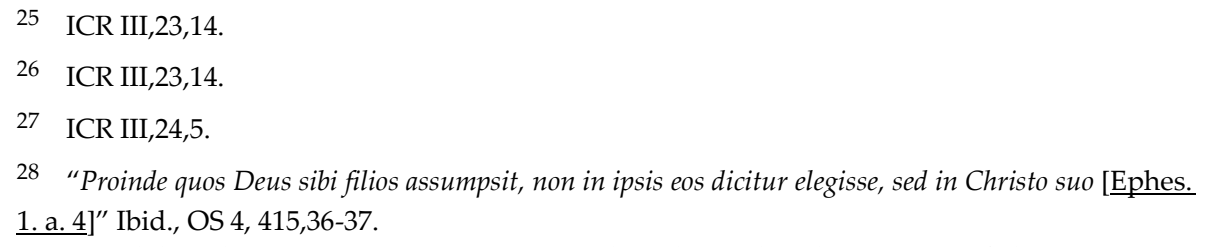

With his Christocentric concentration, Karl Barth develops his doctrine of election in a highly original way. For Barth, predestination is God's covenant of grace in Jesus Christ. "Before Him and without Him and beside Him God does not, then, elect or will anything. And He is the election (and on that account the beginning and the decree and the Word) of the free grace of God" Church Dogmatics, II, 2. The Doctrine of God (Edinburgh: T\&T Clark, 1957), 94.

Although Barth obviously parts way with Calvin and other Reformers, his doctrine of election is consistently related to soteriology. He calls the doctrine of election "the sum of the Gospel because of all words that can be said or heard it is the best" Church Dogmatics, II, 2, 3.

Barth criticizes Calvin's idea of predestination as a mixture of good and horrible news, thus betraying the idea of divine gracious covenant in Christ. Despite its unorthodoxy, Barth's doctrine of election rightly highlights the importance of the soteriological dimension of this doctrine, thus bringing anew the light of the Gospel of Jesus Christ. Jesus is not only the elect but also the reprobate for our sake. "In God's eternal purpose it is God Himself who is rejected in His Son. The self-giving of God consists, the giving and sending of His Son is fulfilled, in the fact that He is rejected in order that we might not be rejected" Church Dogmatics, II, 2, 167.

By taking the rejection of man upon himself, God "elects man to participation in His own glory" Church Dogmatics, II, 2, 94. Gloria deiis the telosof election according to Barth. 
preferred than "through Christ" for the reason that "in Christ" a blessed immortality and glory is already possessed. ${ }^{29}$ In Christ lies the richest consolation and in His person we have a sure pledge and foretaste of all that we need. In His person also will be the revelation of gloria Dei. ${ }^{30}$ Calvin uses the argumentation of Paul's immediate addition of the word Christ in Tit. 2:13 to refute the Arians and to show that the revelation of the glory of "the great God" cannot be thought without Christ.

Not only our election but also the contemplation of our election should happen in Christ as the mirror. Even if the doctrine of election fails to provide the assurance of salvation, a clear and sufficient testimony is given by our true communion with Christ. ${ }^{31}$ Instead of speculating on who belongs to the number of the elect and who does not, Calvin directs our thought to contemplate the free offer of salvation in the preaching of the gospel. ${ }^{32}$ It is through the gospel that the hope of gloria Dei has shone upon us; the gospel is the testimony for our participation of the divine nature. ${ }^{33}$ Christ is our final goal, therefore to ascend above Christ and to seek outside Him are infatuated. C. Link has also pointed out that "a change in attitude" and "a transition to a Christological argument" are to be observed in Calvin's

\footnotetext{
29 Calvin, Comm. Eph. 2:6.

30 Calvin, Comm. Tit. 2:13.

31 "Quum enim is sit cuius corpori inserere destinavit Pater quos ab aeterno voluit esse suos, ut pro filiis habeat quotquot inter eius membra recognoscit, satis perspicuum firmumque testimonium habemus, nos in libro vitae scriptos esse si cum Christo communicamus" ICR III,24,5, OS 4, 416, 5-9.

32 "Porro ille certa sui communione nos donavit, quum per Evangelii praedicationem testatus est se nobis a Patre datum, ut cum suis omnibus bonis noster esset [Rom. 8. f. 32]. [...] Toties repetitur haec doctrina, Filio unigenito non pepercit Pater, utquisquis credit in eum, non pereat [Iohan. 3. b. 15]" ICR III, 24, 5, OS 4, 416, 9-15.

33 Calvin, Comm. Rom. 1:2.
} 
theological thought: the pretemporal nature of election that departs from causal thinking is replaced by the eschatological argument, an approach that directs our mind to the future of God. ${ }^{34}$ Even if one might suspect that this idea could arise from a Barthian interpretation on Calvin's theology, it is to be noted that the universalistic aspect of predestination flowed originally from Calvin himself.

\section{The Relation of God' Glory to His Grace}

In his commentary on Rom. 9:22-23, Calvin explains that the destruction of the reprobate has two reasons: the ministration of divine power and the greatness of divine mercy towards the elect. Both demonstrations of divine judgment and divine mercy manifest the glory of God. Although the preparation of the elect and the reprobate is related with God's secret counsel, Calvin emphasizes that the word gloria cannot be understood outside the experience of salvation:

The word glory, which is here twice mentioned, I consider to have been used for God's mercy, a metonymy of effect for the cause; for his chief praise or glory is in acts of kindness. ${ }^{35}$

The same tenor is to be found in the commentary on Eph. 1:12. After explaining the counsel of God's own will as the actual cause of election in V. 11, Calvin emphasizes the understanding of gloria Dei from the perspective

\footnotetext{
34 Christian Link, "Election and Predestination," in John Calvin's Impact on Church and Society, 1509-2009, ed. Martin Ernst Hirzel\& Martin Sallmann (Grand Rapids: Eerdmans, 2009), 117.

35 "'Gloriae' vocabulum, quod bis hic repetitur, interpretor positum pro 'misericordia Dei' metwnumikw/j; quia praecipua eius laus est in benefactis" Calvin, Comm. Rom. 9:22-23, Opera exegetica Veteris et Novi Testamenti, Vol. 13, 206, 40-207, 1. ; trans. by John Owen.
} 
of God's goodness, thus securing a certain worldview of the redeemed:

The word glory, by way of eminence, ( $\left.\kappa \alpha \tau^{\prime} \dot{\varepsilon} \xi o x \eta \dot{\eta} v\right)$ denotes, in a peculiar manner, that which shines in the goodness of God; for there is nothing that is more peculiarly his own, or in which he desires more to be glorified, than goodness. ${ }^{36}$

A Cartesian view of gloria Dei, which tries to observe God's sovereign will from a 'neutral' point of view, is thus not advocated by Calvin. Either one accepts and practices the understanding of God's glory in his secret counsel from the point of view of the elect, i.e. of someone who has experienced God's mercy and kindness, or one denies God's sovereign decree from the point of view of the reprobate, who in fact does not really care whether God is sovereign or not.

Calvin's thought on the relation of God's grace to God's glory has been also criticized by Kuizenga. Quoting Calvin in his commentary on Psalms, Kuizenga postulates that God's greatest glory is realized in showing mercy in human salvation. ${ }^{37}$ This is the first level of God's operation in accomplishing his glory. However, God also operates on the second level to accomplish his glory in the reprobation. Kuizenga supports his opinion by a passage from the Institutes. ${ }^{38}$ He keeps questioning why God should satisfy

\footnotetext{
36 "Nomen gloriae kat v evxoch.n, peculariter eam significat, quae elucet in Dei bonitate. Nihil enim magis est illi proprium, in quo glorificari velit, quam bonitas" Calvin, Comm. Eph. 1:12, in Ioannis Calvini Opera quaesupersuntomnia $[=\mathrm{CO}]$ 51, 152, ed. G. Baum, E. Cunitz, and E. Reuss, 58 vols., 1863-1900; English translation by William Pringle.

37 Henry Kuizenga, "The Relation of God's Grace to His Glory in John Calvin," in Reformation Studies: Essays in Honor of Roland H. Bainton(Richmond: John Knox Press, 1962), 105; cf. "Imo Paulus Rom. 3, 23 de ea loquens, gloriam Dei generaliter kat' evxoch.n nominat: ac si diceret, Deum, qui in cunctis suis operibus summam laudem meretur, velle tamen praecipue glorificari in sua misericordia" Calvin, Comm. Ps. 136:1, CR 60, 363.

38 "Ergo, ut solos electos semine incorruptibili Deus in perpetuum regenerat, ut nunquam dispereat
} 
himself with such "inferior" glory when he already realizes the greatest glory in the work of redemption. At the end of his study he leaves Calvin with two options: either the teaching on God's nature and God's grace or the teaching on the decree of reprobation must be repudiated. However, against Kuizenga, there is another alternative to interpret Calvin's teaching on reprobation as an inferior operation of the Spirit. By using the term inferior operation Calvin does not refer to the inferior glory realized by God but to the inferior working of the Spirit in ascribing temporary faith among the reprobate. Since such faith is not permanent such as given to the elect it is called God's "inferior" working. When Calvin calls the reprobation an inferior operation, it is plain that first, he does not understand election and reprobation as parallel ways under the umbrella of divine sovereignty; secondly, the presence of gloria Dei in God's various operations is not equal but is realized in different degrees of glory according to the contextsensibility of the Spirit. ${ }^{39}$

It is not that God works distinctively in realizing his glory toward humankind. When the glory of God fails to excite the reprobate's admiration, it is due to their own blindness in their reception of God's

\footnotetext{
semen vitae eorum cordibus insitum: ita solide in illis obsignat adoptionis suae gratiam, ut stabilis ac rata sit. Sed hoc minime obstat quin illa inferior Spiritus operatio cursum suum habeat etiam in reprobis" ICR III,2,11, OS 4, 21,9-14.

39 Yong has pleaded for a pneumatological theology of religions whose task is to engage the reality of the different degrees of divine presence and activity. The naïve paradigm of intractable dualisms such as the categorization into those who are saved and lost is found no longer adequate. Instead, a theological discernment to identify the divine presence or absence at various degrees of religious phenomenon is needed than ever; cf. Amos Yong, "Discerning the Spirit(s) in the World of Religions: Toward a Pneumatological Theology of Religions", in No Other Gods Before Me?: Evangelical and the Challenge of World Religions, ed. John G.

Stackhouse(Grand Rapids: Baker Academic, 2001), 49-52.
} 
works. ${ }^{40}$ God cannot be held accountable for discriminatively expressing his glory.

The glory of God was not a daily manifestation for the children of Israel but a manifestation "in an unusual manner to inspire alarm; because they were hardened against its ordinary manifestations". ${ }^{41}$ Still in the commentary on the same chapter of Exodus Calvin explains that the brightness of God's glorious countenance is to remind the children of Israel of their impiety and to humble them with shame for the manna was not given by God in return for their murmurings. ${ }^{42}$ Here, Calvin understands the ordinary manifestations of the glory of God in the context of divine providence. The unusual manner of its manifestation is used to display God's transcendence in his free judgment on human sins. Finally, for his own people, the unusual appearance of his glory, which includes warning, is again to confirm his faithful providential grace to the elect.

\section{The Reception of Calvin's Doctrine of Predestination in Westminster Larger Catechism}

The issue of predestination is discussed under the doctrine of God, more precisely, the doctrine of God's decrees. The key text can be found in Q\&A 12-13.

\footnotetext{
40 Calvin, Comm. Num. 14:41.

41 Calvin, Comm. Ex. 16:9-10.

42 Calvin, Comm. Ex. 16:6-8.
} 
Q. 12. What are the decrees of God?

A. God's decrees are the wise, free, and holy acts of the counsel of his will, whereby, from all eternity, he hath, for his own glory, unchangeably foreordained whatsoever comes to pass in time, especially concerning angels and men.

There are some points to be considered here. First, the placement of predestination in the doctrine of divine decree looses the important soteriological dimension as attested in Calvin's thought. The doctrine of divine decrees encompasses not only predestination of some to salvation but even "whatsoever comes to pass in time". Following Q\&A 12 we then read:

Q. 13. What hath God especially decreed concerning angels and men?

A. God, by an eternal and immutable decree, out of his mere love, for the praise of his glorious grace, to be manifested in due time, hath elected some angels to glory; and in Christ hath chosen some men to eternal life, and the means thereof: and also, according to his sovereign power, and the unsearchable counsel of his own will, (whereby he extendeth or withholdeth favor as he pleaseth,) hath passed by and foreordained the rest to dishonor and wrath, to be for their sin inflicted, to the praise of the glory of his justice.

From the question we can conclude that predestination is a special decree of God. Note that both election and reprobation are put in a parallel just a position to each other, thus in a more symmetrical way compared to Calvin. Both election and reprobation are divine foreordination. The only nuance of asymmetrical notion is found in the use of "hath passed by". Such strict parallelization can only be explained from the perspective of God's glory. Thus, both in Q\&A 12 and 13 we find "for his own glory" and "to the praise of the glory of his justice" as the telos of predestination. Now Gloria deibecomes not only a key but even the key to understand the mystery of divine predestination. 


\section{Conclusion}

The doctrine of predestination is not the center of Calvin's theology. Calvin could speak of election both in relation to the doctrine of God's providential decree and to the doctrine of salvation. There is a certain tension, albeit a creative one, between viewing election as predestination and as good news. The reception of Calvin's theology in the thought of Karl Barth is that of the soteriological aspect. On the other hand, Westminster Larger Catechism emphasizes the aspect God's decree in predestination. Both schools of thought are within the limits of Calvin's theology alone. Despite the aspect of God's sovereignty in his theology concerning predestination, Calvin rejects the distinction between potentia absoluta dei and potentia ordinata dei advocated in medieval theology. Belief in God's sovereignty is not the same as belief in a tyrannical God. Despite his exposition on double predestination, Calvin still differentiates between election and reprobation: it is not the same level operation of the Holy Spirit. Reprobation is an inferior operation of the Holy Spirit compared to election. Here, there is a certain aspect of single predestination in Calvin's thought. Even Westminster Larger Catechism which advocates the doctrine of predestination in a strict parallel sense, still uses the term passing by when explaining the reality of reprobation. A key to understand Calvin's complex view on predestination can be offered from the perspective of gloria dei. Both election as good news and election as God's decree in predestination refer to the glory of God as their telos. Election as good news witnesses God's glory in his gracious salvation to humanity; as well, predestination which also includes reprobation demonstrates God's glory of his justice towards human 
sinfulness. Not only in Calvin, but also in medieval theology, Beza, Westminster Larger Catechism, and Karl Barth, gloria dei remains a significant key for understanding the issue of predestination. Sola dei gloria. 